\title{
Gambaran Pengetahuan dan Sikap Ibu tentang Pemberian Imunisasi Measles Rubella (MR) pada Balita di Puskesmas Tahtul Yaman Kota Jambi
}

\author{
Fitri Ramadani ${ }^{1}$, Tuhu Perwitasari ${ }^{2}$, Aryani Puspasari $^{3}$ \\ ${ }^{1,2}$ Prodi DIII Kebidanan STIKes Baiturrahim Jambi \\ ${ }^{3}$ Dinas Kesehatan Kota Jambi \\ Email :fr0547711@gmail.com
}

Published: 14/03/2020

\begin{abstract}
Measles and rubella are two infectious diseases that are very contagious. Caused by a virus in general, both of these diseases have no treatment, but can be prevented by immunization. Toddler mortality rate in the world reaches 34/1000 live births caused by various diseases that can actually be prevented by immunization. This study aimed to determine the description of knowledge and mother's attitude about measles rubella $(M R)$ in toddlers at the public health center Tahtul Yaman Jambi city year 2019. This is a descriptive research. It was conducted on August 19-23 2019. Populations were all off toddler's mother as many as 992. Samples were 42 respondents by using accidental sampling technique. The collecting of data used a questionnaire. It analyzed as univariate. The findings were obtained that most of respondents did not provide MR immunization for toddlers as many as $71 \%$. Most of respondents have enough knowledge as many as $55 \%$. Most of respondents have positive attitude as many as $60 \%$. This study can be concluded that most of respondents did not provide MR immunization for toddlers, has sufficient knowledge and a positive attitude. Health personal at the public health center should make a schedule of counseling, information and education about MR immunization by using media that is interesting and easily understood by the community especially toddler's mothers. The public health center should cooperate with the department of religion, community leaders and religious leaders to work together in synergy to disseminate information about the importance of MR immunization.
\end{abstract}

Keywords : attitude, knowledge, MR Immunization

\begin{abstract}
Abstrak
Measles atau yang dikenal dalam Bahasa Indonesia campak, dan Rubella atau campak Jerman, merupakan dua penyakit infeksi yang sangat menular. Kedua penyakit ini tidak memiliki pengobatan, tetapi dapat dicegah dengan imunisasi. Angka Kematian Balita (AKABA) di dunia mencapai 34/1000 kelahiran hidup yang disebabkan dari berbagai penyakit yang sebenarnya dapat dicegah dengan imunisasi. Tujuan penelitian ini adalah untuk mengetahui Gambaran Pengetahun Dan Sikap Ibu Tentang Pemberian Imunisasi Measles Rubella (MR) Pada Balita Di Puskesma Tahtul Yaman Kota Jambi Tahun 2019. Penelitian ini merupakan penelitian deskriptif. Dilaksanakan pada tanggal 19-23 Agustus 2019 Populasi dalam penelitian ini adalah seluruh ibu balita sebanyak 992. Sampel diambil dengan teknik Accidental Sampling sebanyak 42 responden . Metode pengumpulan data dilakukan dengan pengisian kuesioner. Analisis data dalam penelitian ini adalah analisis univariat. Dari 42 responden didapat bahwa sebagian besar responden tidak memberikan imunisasi MR pada balitanya yaitu sebanyak $71 \%$. Sebagian besar responden memiliki pengetahuan yang cukup yaitu sebanyak 55\%. Sebagian besar responden memiliki sikap yang positif yaitu sebanyak $60 \%$. Dapat disimpulkan bahwa sebagian besar responden tidak memberikan imunisasi MR pada balitanya, memiliki pengetahuan cukup dan sikap positif. Petugas kesehatan di Puskesmas sebaiknya membuat jadwal Konseling, Informasi dan Edukasi (KIE) mengenai imunisasi MR dengan menggunakan media yang menarik dan mudah dipahami oleh masyarakat terutama ibu balita. Puskesmas sebaiknya juga melakukan kerja sama dengan
\end{abstract}


departemen agama, tokoh masyarakat dan tokoh agama untuk bersama sama secara sinergis melakukan sosialisasi tentang pentingnya imunisasi MR.

Kata Kunci : imunisasi MR pengetahuan, sikap

\section{PENDAHULUAN}

Balita adalah anak yang berumur 0-59 bulan. Masa ini adalah periode yang sangat penting bagi tumbuh kembangnya sehingga biasa disebut dengan golden period yang mana pada masa ini pertumbuhan dan perkembangan anak sangat pesat baik secara fisik, psikologi, mental, maupun sosialnya (Unicef, 2012).

Menurut World Health Organization (WHO), pada tahun 2013 Angka Kematian Balita (AKABA) di dunia 34 per 1.000 kelahiran hidup, AKABA di negara berkembang 37 per 1.000 kelahiran hidup dan AKABA di negara maju 5 per 1.000 kelahiran hidup. Pada tahun 2013 AKABA di Indonesia mencapai 25 per 1.000 kelahiran hidup. Bila dibandingkan dengan Malaysia, Filipina dan Singapura, angka tersebut lebih besar dibandingkan dengan angka dari negara-negara tersebut dimanabAKABA Malaysia 7 per 1.000 kelahiran hidup, Filipina 24 per 1.000 kelahiran hidup dan Singapura 2 per 1.000 kelahiran hidup.

Imunisasi merupakan suatu upaya untuk menimbulkan atau meningkatkan kekebalan seseorang secara aktif terhadap suatu penyakit. Imunisasi campak dan rubella ditujukan untuk memberikan kekebalan aktif terhadap penyakit campak dan rubella. Balita yang tidak diimunisasi MR akan berisiko untuk menderita campak dan rubella. Komplikasi dari penyakit campak adalah radang paru-paru, infeksi pada telinga, radang pada saraf. Radang pada sendi, dan radang pada otak yang dapat menyebabkan kerusakan-kerusakan otak yang permanen. Terdapat 83 kasus pasti Congenital Rubella Syndrome/CRS pada tahun 2015-2016 diantaranya 77\% menderita kelainan jantung, 67,5\% menderita katarak dan $47 \%$ menderita ketulian (Ditjen P2P, 2016).

Penyakit Campak dan Rubella tidak dapat diobati. Pengobatan yang diberikan kepada penderita hanya bersifat supportif. Tetapi kedua penyakit ini bisa dicegah dengan imunisasi. Selama ini Indonesia memberikan imunisasi Campak sebagai salah satu program imunisasi nasional. Mengingat besarnya perkiraan beban penyakit Rubella dan tersedianya vaksin kombinasi Measles-Rubella (MR), maka diputuskan untuk mengganti vaksin Measles dengan vaksin kombinasi MeaslesRubella, yang dimulai dengan kegiatan imunisasi massal MR (Kemenkes, 2016)

Menurut penelitian Merlinta (2018) yang berjudul "Hubungan Pengetahuan Tentang Vaksin MR dan Pendidikan Ibu Terhadap Minat Keikutsertaan Vaksinasi MR di Puskesmas Kartasura" menunjukkan bahwa sebagian besar responden yang berpendidikan tinggi dan juga berminat dalam keikutsertaan vaksinasi MR di Puskesmas Kartasura yaitu sebanyak (75\%)

Berdasarkan data yang diperoleh dari Dinas Kesehatan Kota Jambi Tahun 2018 cakupan pemberian imunisasi MR sebanyak 23.525 balita $(50.83 \%)$. cakupan pemberian imunisasi MR tertinggi terdapat di Puskesmas Paal Merah II sebanyak 793 balita $(92.86 \%)$ sedangkan terendah terdapat di Puskesmas Tahtul Yaman sebanyak 235 balita (20.26\%) maka peneliti mengambil penelitian di Puskesmas Tahtul Yaman.

Berdasarkan data tersebut, peneliti tertarik untuk melakukan penelitian dengan judul Gambaran Pengetahuan dan Sikap Ibu Tentang Pemberian Measles Rubella (MR) pada Balita di Puskesmas Tahtul Yaman Kota Jambi Tahun 2019. 


\section{METODE PENELITIAN}

Penelitian ini merupakan penelitian deskriptif yang bertujuan untuk mengetahui Gambaran Pengetahuan dan Sikap Ibu tentang Pemberian Imunisasi Measles Rubella (MR) pada Balita di Puskesmas Tahtul Yaman Kota Jambi tahun 2019. Dilaksanakan pada tanggal 1923 Agustus 2019. Populasi dalam penelitian ini adalah seluruh Ibu balita yang berada di Puskesmas Tahtul Yaman yaitu sebanyak 992 Ibu. Sampel diambil dengan teknik Accidental Sampling sebanyak 42 responden. Metode pengumpulan data dilakukan dengan pengisian kuesioner. Analisis data dalam penelitian ini adalah analisis univariat.

\section{HASIL DAN PEMBAHASAN}

A. Gambaran Pemberian Imunisasi MR Pada Balita di Puskesmas Tahtul Yaman Kota Jambi Tahun 2019

Gambar 1. Pemberian imunisasi MR pada balita

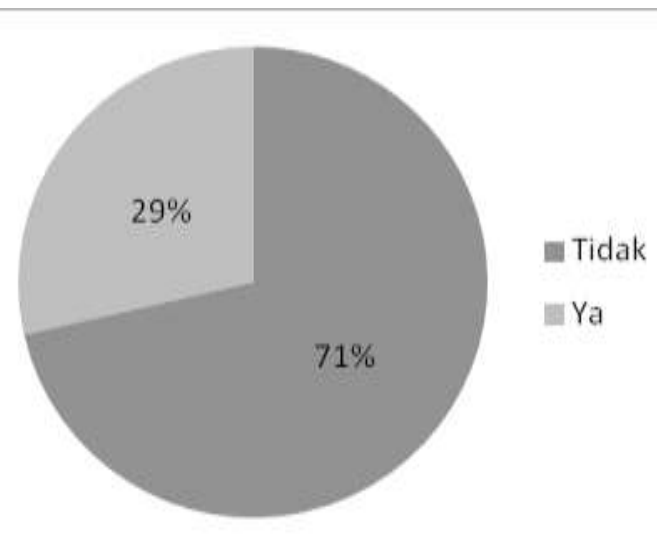

Berdasarkan Gambar 1 dapat diketahui bahwa sebagian besar balita tidak mendapatkan imunisasi MR yaitu sebanyak $71 \%$

Hasil penelitian didapat bahwa sebagian besar responden tidak memberikan imunisasi MR pada balita. Balita yang belum mendapatkan imunisasi MR dipengaruhi oleh pengetahuan responden yang masih kurang mengenai imunisasi MR sehingga membuat pemberian imunisasi masih rendah. Selain itu sikap yang negatif terhadap imunisasi MR membuat orangtua tidak mengimunisasikan MR pada balitanya. Hal ini dapat dilihat dari karakteristik responden masih terdapat ibu balita dengan tingkat pendidikan menengah kebawah yaitu SD \& SMP. Dan sebagian ibu adalah ibu rumah tangga yang tidak bekerja sehingga kemungkinan untuk mendapat akses informasi tentang vaksin MR sangat terbatas.

Hasil penelitian ini berbeda dengan penelitian yang dilakukan oleh Ihsan (2018) mengenai Tindakan Ibu Tentang Pemberian Imunisasi Measles Rubella (MR) Pada Balita di Kelurahan Parupuk Tabing Tahun 2018 didapat bahwa lebih dari setengah responden yang memberikan imunisasi MR pada balitanya.

Upaya yang dapat dilakukan adalah dengan melakukan sosialisasi kepada responden mengingat pentingnya pemberian imunsiasi MR pada balita. Selain itu untuk meningkatkan sikap yang baik dari orangtua juga dibutuhkan peran dari petugas kesehatan yang selalu mensosialisasikan mengenai pemberian MR tidak hanya di dalam gedung namun juga diluar gedung seperti di posyanduposyandu di wilayahnya. Serta memasang poster-poster atau spanduk untuk meningkatkan motivasi dari masyarakat untuk memberikan imunisasi MR pada balita. Serta peran kader juga sebaiknya lebih ditingkatkan untuk membantu petugas kesehatan dalam menginformasikan kepada masyarakat. 
1. Alasan responden tidak memberikan imunisasi MR pada balita

\begin{tabular}{|c|c|c|}
\hline $\begin{array}{l}\text { Tabel 1. Distri } \\
\text { Berdasarkan alasa } \\
\text { memberikan Imunisa } \\
\text { di Puskesmas Tahtul } \\
\text { Tahun 2019 }\end{array}$ & Ib & $\begin{array}{r}\text { ponden } \\
\text { tidak } \\
\text { Balita } \\
\text { Jambi }\end{array}$ \\
\hline Alasan & n & $\%$ \\
\hline Vaksin tidak halal & 16 & 53,3 \\
\hline $\begin{array}{l}\text { Baru pertama kali } \\
\text { diberikan di Kota } \\
\text { Jambi }\end{array}$ & 7 & 23,3 \\
\hline $\begin{array}{l}\text { Balita sudah mendapat } \\
\text { imunisasi campak }\end{array}$ & 7 & 23,3 \\
\hline Total & 30 & 100 \\
\hline
\end{tabular}

Berdasarkan tabel 1 dapat diketahui bahwa sebagian besar alasan responden tidak memberikan imunisasi MR pada balita adalah karena adanya rumor tentang vaksin yang tidak halal yaitu sebanyak $53,3 \%$. Hasil penelitian didapat bahwa sebagian besar alasan responden tidak memberikan imunisasi MR pada balita adalah karena dipengaruhi oleh adanya rumor dan informasi yang salah tentang vaksin MR yang tidak halal. Hal ini dapat dilihat dari mayoritas agama penduduk setempat adalah Muslim yang beranggapan vaksin yang tidak halal tidak boleh diberikan.

Upaya yang dapat dilakukan adalah dengan lebih meningkatkan pendekatan kepada masyarakat dengan melibatkan orang yang dipercaya dan berpengaruh ditempat tersebut seperti tokoh agama untuk ikut menjelaskan kepada masyarakat bahwa imunisasi MR aman dan halal untuk diberikan kepada balita.

\section{B. Gambaran Pengetahuan Ibu tentang Pemberian Imunisasi MR pada Balita di Puskesmas Tahtul Yaman Kota Jambi Tahun 2019}

Tabel 2. Distribusi Pengetahuan Ibu tentang Pemberian Imunisasi MR

\begin{tabular}{ccc}
\hline $\begin{array}{c}\text { Pengetahu } \\
\text { an }\end{array}$ & Frequensi & Persentase(\%) \\
\hline $\begin{array}{c}\text { Kurang } \\
\text { baik }\end{array}$ & 6 & 21 \\
$\begin{array}{c}\text { Cukup } \\
\text { baik }\end{array}$ & 7 & 24 \\
& 17 & 55 \\
\hline Total & 30 & 100 \\
\hline
\end{tabular}

Berdasarkan Tabel 2 dapat diketahui bahwa sebagian responden memiliki pengetahuan yang cukup yaitu sebanyak $55 \%$. Hasil penelitian didapat bahwa pengetahuan ibu tentang pemberian imunisasi MR pada balita di Puskesmas Tahtul Yaman Kota Jambi Tahun 2019 sebagian besar responden memiliki pengetahuan yang cukup.

Pada penelitian lain hasil penelitian berbanding terbalik dengan penelitian Lailan Najah (2018). Dimana hasil penelitiannya yaitu tingkat pengetahuan ibu yang tinggi juga sesuai dengan pemberian imunisasi yang tinggi.

Pada penelitian ini hasil penelitian berbanding terbalik dengan teori dimana seharusnya pengetahuan dan sikap yang baik akan mempengaruhi responden dalam mengambil keputusan untuk memberi imunisasi MR pada balitanya. Hal ini dipengaruhi oleh adanya rumor dan informasi yang salah tentang vaksin MR yang tidak halal. Menurut Harahap dkk (2019) tingkat pengetahuan rendah dipengaruhi oleh seperti umur ibu balita yang masih muda ( $<20$ tahun), pendidikan ibu masih ada menengah kebawah seperti SD dan SMP serta sebagian besar ibu tidak bekerja (IRT) sehingga memperoleh akses informasi berkurang.

Upaya yang dapat dilakukan adalah dengan bekerja sama dengan berbagai pihak penting seperti lintas terkait, dinas kesehatan, dinas pendidikan, dan departemen agama. Walaupun sebagian besar pengetahuan responden sudah cukup 
namun tenaga kesehatan harus tetap memberi penyuluhan-penyuluhan tentang imunisasi MR. Meningkatkan sosialisasi, konseling, edukasi, pentingnya imunisasi MR dan dampak balita jika tidak diberikan imunisasi MR. Meningkatkan fungsi media promosi dengan melakukan pemasangan spanduk, pemasangan leaflet, pemberian stiker.

C. Gambaran Sikap Ibu tentang Pemberian Imunisasi MR pada Balita di Puskesmas Tahtul Yaman Kota Jambi Tahun 2019

Berdasarkan Gambar 3. dapat diketahui bahwa sebagian besar responden memiliki sikap positif yaitu sebanyak $60 \%$. Berdasarkan hasil penelitian didapat bahwa sikap ibu tentang pemberian imunisasi measles rubella (MR) pada balita di Puskesmas Tahtul Yaman Kota Jambi Tahun 2019 sebagian besar responden memiliki sikap positif.

Gambar 3. Distribusi Sikap Ibu tentang Pemberian Imunisasi MR

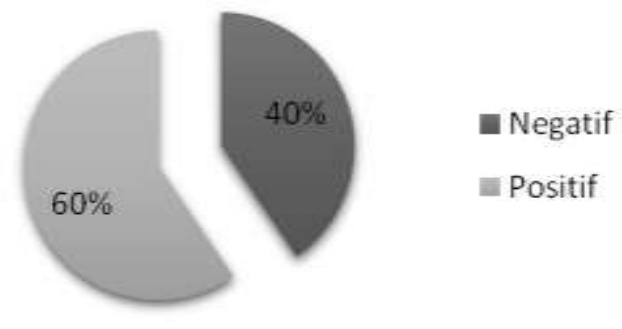

Hasil penelitian ini sejalan dengan penelitian Ihsan (2018) mengenai Sikap Ibu Tentang Pemberian Imunisasi MeaslesRubella (MR) Pada Balita didapat bahwa gambaran sikap ibu terhadap imunisasi MR di Kelurahan Parupuk Tabing adalah positif .

Dalam penelitian ini responden yang memiliki sikap negatif terhadap pemberian imunisasi MR disebabkan oleh beberapa faktor, yaitu faktor kehalalan vaksin MR yang digunakan, faktor penolakan dari sisi agama, dan faktor media massa yang tersebar kemasyarakat tentang efek samping imunisasi MR sampai adanya kematian.

\section{SIMPULAN}

Berdasarkan penelitian dapat ditarik kesimpulan bahwa dari 42 responden sebagian besar responden tidak memberikan imunisasi MR pada balitanya, memiliki pengetahuan yang cukup, dan memiliki sikap yang positif

Perlunya peningkatan upaya promosi kesehatan tentang pentingnya imunisasi MR pada balita, dengan melibatkan dinas kesehatan, perangkat pemerintah, dinas pendidikan, departeme agama, serta tokoh agama untuk menginformasikan kehalalan vaksin yang sudah bersertifikat MUI.

\section{UCAPAN TERIMAKASIH}

Penulis mengucapkan terimakasih kepada Puskesmas Tahtul Yaman Kota Jambi yang telah mengizinkan peneliti melakukan penelitian.

\section{DAFTAR PUSTAKA}

Dinkes Kota Jambi. (2018).Profil Dinas Kesehatan Kota Jambi

Ditjen P2P, K.R.,(2016). Petunjuk Teknis Kampanye Imunisasi Measles Rubella (MR). Jakarta: Kemenkes RI

Harahap RR, Perwitasari T, Puspasari A. Gambaran Pengetahuan dan Motivasi Ibu Tentang Pemberian Imunisasi DPT Lanjutan (Booster) Di Puskesmas Simpang IV Sipin Kota Jambi. Jurnal Akademika Baiturrahim. 8 (2): 218-223.

Ihsan. (2013) Dasar Dasar Kependidikan :Komponen MKDK. Jakarta: Rineka Cipta

Kementerian Kesehatan RI. (2016) buku ajar imunisasi. Kemenkes RI

Merlinta. (2018). Hubungan Pengetahuan Tentang Vaksin MR (Measles Rubella) dan Pendidikan Ibu 
Jurnal Akademika Baiturrahim Jambi, Vol. 9, No.1 Maret 2020

Doi: $10.36565 /$ jab.v9i1.148

p-ISSN :2302-8416

e-ISSN: 2654-2552

Terhadap Minat Keikutsertaan

Vaksinasi $\mathrm{Mr} \quad \mathrm{Di} \quad$ Puskesmas

Kartasura. Jurnal Universitas

Muhammadiyah Surakarta

Najah. L, (2018) Tingkat Pengetahuan ibu tentang imunisasi tambahan Measles Rubella (MR) pada balita: Yogyakarta

UNICEF. (2012) Pusat Promosi Kesehatan Kemenetrian Kesehatan RI :Jakarta

WHO. (2013) Maternal Mortality: World Health Organization 